\title{
Intercultural Awareness Training: Contrast Culture Method for Language Educators
}

\section{Alan Simpson \\ Miyazaki International College}

\section{Amanda Gillis-Furutaka \\ Kyoto Sangyo University}

\section{Alexis Pusina}

Tokyo International University

\section{Daniel Lilley}

\section{Osaka Gakuin University}

\section{Margaret Kim}

Otemae University

\section{Reference Data:}

Simpson, A., Gillis-Furutaka, A., Pusina, A., Lilley, D., \& Kim, M. (2019). Intercultural awareness training: Contrast culture method for language educators. In P. Clements, A. Krause, \& P. Bennett (Eds.), Diversity and inclusion. Tokyo: JALT.

This paper presents the implementation and evaluation of a contrast culture method (CCM) training workshop. CCM uses role-play scenarios that highlight the cultural values and assumptions of trainees. One role-player engages in interaction using behaviour and cultural markers familiar to the trainees, while the other presents contrasting behaviours. Trainees have the opportunity to question the role-players while they are in character and to discuss new insights into their assumptions and biases. The authors outline the steps taken in designing and performing a scenario for JALT attendees, primarily language educators. They also discuss the process of recording and analysing the transcript of the training session and follow-up questionnaires to evaluate the responses of the trainees and suggest design improvements for future CCM training sessions.

本稿では、コントラスト・カルチャー・メソッドという文化対照法(以下CCM)を用いたワークショップの実施と評価について 考察する。CCMでは、研修生の文化的な価値観と思い込みを強調するシナリオをロールプレイする。ロールプレイの役者が研 修生の慣れ䅐しんた文化や行動に基ついて演技をし、対照的な立場をもう一人の役者が演技する。研修生か、役になりきって いる役者に貝同し、意見交換するてとて、一人一人の思い込みや偏見について、新たな発見や埋解がでさるようになる。著者 らは、JALT奉加者(主に言語教育者)のためにデサイイしたシナリオと、実施のための手順を概説する。研修生の反応を評価 するため、トレーニング・セッションとフォローアップ・アンケートを分析し、プロセスを考察する。また、今後CCMをどう改善し、 より良い効果が得られるのかを提案する。

$\checkmark$ he contrast culture method (CCM) is a holistic intercultural education training method for raising awareness of one's own culture in order to be sensitive to cultural differences and more open-minded and flexible when dealing with people from different cultures (Hiratsuka, 2015). Culture is related to how we think, consciously or unconsciously, that things are normally done (Stewart, 1995). According to Stewart, culture is "an organization of diversity, not uniformity" (p. 56). CCM sees cultural differences as resources to be used wisely to benefit all. It is an experiential learning process based on psychological, sociological, and anthropological influences, as explained by Stewart in his cultural trilogy framework (Wasilewski \& Kawakami, 2012).

CCM creates an intercultural context through a dynamic and unscripted role-play, tailored for the audience. The audience members are referred to as trainees, because they are not only participants, they are the central focus. The aim is for trainees to gain awareness of their own personal values and belief systems through recognizing and analysing certain contrasting values or behaviours. They are encouraged to share their perceptions through discussion to gain deeper cultural insights. There are, 
however, few indications in the literature as to how to effectively evaluate the extent to which trainees increase awareness of their own cultural values and those of the contrast culture (Kimmel, 1995; Hiratsuka, 2015). Therefore, we aim to develop clearer, systematic evaluation methods that will help guide the implementation of CCM as an intercultural training tool. In this article, we describe the preparation, implementation, and evaluation stages of the CCM training workshop. We also explain how data was gathered and evaluated through video recordings, transcriptions, and questionnaires. Finally, we consider improvements in the design of future CCM sessions, as encouraged by Hiratsuka.

\section{Background to CCM}

In the late 1950s and early 1960s Dr. Edward Stewart studied data about interactions between Americans working overseas and their local counterparts in Laos. He realised that the Americans were making incorrect judgments about the Lao people because they were basing their evaluations on their own American cultural assumptions, and that the interpersonal dimensions of cross-cultural communication had been neglected (Wasilewski \& Kawakami, 2012). This led to the development of a training method that became known as the contrast-American exercise (Kimmel, 1995). Although this exercise was originally designed to contrast white, middle-class American cultural norms in order to train Americans going abroad, it evolved into CCM and was used worldwide and became culturally nonspecific. This means that CCM does not contrast one particular culture with another. Instead, the reference-culture role-player understands and demonstrates values and behaviours that are familiar to the trainees. The contrastculture role-player reacts to the reference-culture role-player in contrasting ways, with both role-players using various pragmatic devices to highlight these contrasting attitudes and values.

\section{CCM Training Evaluation}

In 1999, the Society for Intercultural Education, Training and Research (SIETAR) Japan started the CCM Special Interest Group whose members have conducted numerous study sessions, presentations, and workshops. Fujimoto (2004) reproduced Stewart and his team's detailed summary of cultural assumptions and values (Stewart, Danielian, \& Foster, 1969), including the categories of (a) definitions of activity, (b) definition of social relations, (c) motivation, (d) perception of the world, (e) perceptions of the self and the individual, and (f) generalized forms. However, these categories are based on contrast American cultural values, and a list of contrast Japanese cultural values and assumptions has not been made. Instead, the CCM SIG members used consensus to develop, decide on, and practice representing different values for different audiences, such as Japanese high school teachers or university exchange students (Fujimoto 2004). They videorecorded five CCM sessions in March 2000 and analysed their findings. Their analysis showed contrasts between the role-players in their working styles, with variations in nonverbal and speaking behaviour, listener responses, and pragmatic strategies. These videos were used to better understand the CCM and also to develop pedagogical materials for the university classroom.

Until now, there has only been one longitudinal investigation of the impact of the CCM (Hiratsuka \& Fujimoto, 2012). The posttraining evaluation used interviews that were conducted with different groups of international students at a Japanese university. The interviews included opportunities to write words, phrases, and pictures on whiteboards, and resulted in a cultural transition ability matrix. The categories were (a) developing an ability to observe one's reactions and behaviours in intercultural settings, (b) developing problem analysis and resolution skills in intercultural settings, and (c) gaining an attitude of tolerance/acceptance toward a culture other than one's own. A pretraining needs analysis as well as the matrix and text analysis of interviews showed evidence of improved student awareness and changes in their attitudes and behaviours. However, Hiratsuka and Fujimoto thought that interviewing only one time was not a good enough method to understand actual changes in participant actions and attitudes.

The most recent study to evaluate the effectiveness of CCM training for international graduate students in Japan (Hiratsuka, Suzuki, \& Pusina, 2016) was carried out with a focus group of eight people. The researchers used both audio and video recordings of the group's discussion, transcribed the discussion, and analysed the data using the grounded theory approach to conceptualize the themes from the data. Although the sample size was small, they derived useful findings for future CCM training workshops, such as the recommendation to avoid using a reference culture role-player who is actually from the host culture because this led to stereotyping by the trainees who could easily project their own real-life experiences directly onto the role-players.

There has been no further evaluative work reported and no discussion of the effectiveness of short CCM sessions. Therefore, we decided to film the workshop and collect written feedback through questionnaires in order to investigate the following:

1. What variables during the implementation of a training session influence the outcome of the CCM method?

2. In a short CCM workshop, to what degree can trainees relate to the values that the role-players represent? 
3. Can CCM practioners measure outcomes effectively through existing evaluation methods, and what are the limitations?

\section{Methodology}

In response to the lack of a clear instructional framework of CCM methodology, Hiratsuka (2015) published a training guide on the implementation of the CCM method. Operational aspects have been discussed by Kimmel (1995) and Hiratsuka and Fujimoto (2012), but Hiratsuka (2015) clearly outlined a methodological overview and guide to implementation of CCM training. We summarized the implementation steps into the ADDIE instructional model in Figure 1, to provide a framework for the CCM methodology.

\begin{tabular}{|l|l|}
\hline Analysis phase & $\begin{array}{l}\text { Predicting trainee characteristics and potential intercultural } \\
\text { contrasts }\end{array}$ \\
\hline Design phase & Discussing approach to meet training objectives \\
\hline Development phase & Developing and confirming training approach \\
\hline Implementation phase & $\begin{array}{l}\text { Setting up, implementing and facilitating role-play scenario } \\
\text { and group discussion }\end{array}$ \\
\hline Evaluation phase & Evaluating the training quality and process \\
\hline
\end{tabular}

Figure 1. The ADDIE model, adapted from Branch, 2009.

\section{Analysis, Design, \& Development}

The analysis phase was conducted through online video conversations that identified the kinds of interpersonal dynamics and situations that the trainees (a Japan Association for Language Teaching conference audience) might be able to relate to. It was agreed that the scenario would be an academic environment where intercultural differences would influence the approach and implementation of work-related tasks. The details were refined during the design phase.

The most difficult part was the development stage. A scenario needs to show contrast between the role-players, but also be realistic enough for the trainees to be able to identify with the situation. Stewart (1995) suggested that "trainees develop cultural awareness and understanding of their own culture only when role-playing provides a comparison with another culture" (p. 51). The trainees should focus on identifying contrasts and similarities in behaviours and values while avoiding stereotyping and cultural assumptions. Therefore, the finalised scenario was as follows:

Two colleagues have received an order from the administration of their institution to set up an "English zone" (a space on campus where students can practice and study English informally). The two colleagues approach this project with different attitudes. One has worked for the institution for many years, is experienced in this kind of project work, and takes a realistic approach. (S/he represents the contrast culture). The other is new to the institution, is very enthusiastic about the project and about being assigned such a task, and wants to get to work straight away. (S/he represents the reference culture).

This was a dynamic development phase, with multiple collaborators and many practice role-plays with trainers playing different roles. These practice sessions enabled the trainers to assess and evaluate the interpersonal dynamics, the contrasts, and the authenticity of the interaction (Hiratsuka, 2015). In addition, the trainers were able to identify eight recurring themes that arose in the practice sessions:

1. Temporality-importance of short or long-term results or actions,

2. Hierarchy-hierarchy and leadership,

3. Relationship and Face-importance of face and reputation,

4. Risk-willingness to accept risk and take challenges,

5. Process-importance on due process and planning of goal orientation,

6. Group Orientation-individualistic or group-oriented,

7. Motivation-basis of motivation,

8. Progressiveness-making changes and willingness to adopt new ideas.

CCM demonstrates extreme ends of the spectrum for these themes so that they are contrasted sufficiently for the trainees to recognise them. However, when evaluating, it is important to consider the degree to which these have been represented.

\section{Implementation}

At the implementation stage, we made sure that the role-players had not acted in the same roles with each other beforehand so that their interaction would be realistic, fresh, and spontaneous. A common practice when conducting a CCM training session is to designate one practitioner to interview both role-players and act as the overall facilitator. However, in this workshop there were two interviewers and a facilitator. The facilitator's
MFRONT PAGE

4 PREVIOUS PAGE
ONLINE

FULL SCREEN 
role is to introduce and explain the CCM and the steps of the role-play, interviews, and discussion. During this introduction the facilitator stressed that the trainees should not problem-solve, focus on minute details, or express judgmental opinions. The time required to conduct the following steps of the CCM training can vary, however in this training session there was a limited time period of only 50 minutes:

1. CCM introduction and instructions for trainees;

2. Role-play;

3. Reference role-player interview;

4. Contrast role-player interview;

5. Group discussion about issues raised, sharing of reactions and perceptions;

6. Wrap-up summary and self-reflection surveys.

\section{Evaluation}

Two means of evaluation were used. The first was a video recording of the whole workshop that was later transcribed and analysed for comments or views related to the eight target themes described above. We analysed the transcript to identify: (a) how the trainees connected with the values that were being represented in the role-play and (b) the degree to which the trainees revealed their values. Examples were categorized according to similarity with our anticipated themes and the values expressed by the trainees.

The second evaluation method was a short questionnaire filled out by the trainees consisting of three reflective questions:

1. Do you feel this session was useful for you? Why? Why not?

2. What values or ideas did you relate to the most, and why?

3. Please write a paragraph about your experience and thoughts in this session. Evidence of themes and values were extracted from the video transcriptions and categorized (see Appendix A). Appendix B shows evidence from the questionnaires.

\section{Results and Discussion}

Seven people joined the workshop, four participated in the discussion, and three submitted the questionnaire. The video transcription extracts were coded with the roleplaying actors being $\mathrm{A} 1$ (reference) and A2 (contrast) and the trainees being $\mathrm{T} 1, \mathrm{~T} 2, \mathrm{~T} 3$, and T4.

\section{Implementation}

It was assumed that the trainees would be mainly university educators. Therefore, a university-based project scenario was developed and enacted, with two members of faculty having contrasting communication styles and thinking. It was important to try not to make it a culturally specific setting, so that trainees from varied cultural backgrounds would be able to identify different behaviours and relate them to their own values without making cultural assumptions. However, one of the role-players accidentally used the Japanese word, kyojukai (faculty meeting), which made it clear to the trainees that it was a Japanese setting. This narrowed the trainee focus to contrast with Japanese cultural values in this situation. However, the trainees continued to identify with both role-players to varying degrees.

An important point when facilitating a CCM training session is ensuring trainees remain objective in their views and comments. The facilitators' role is to manage the phrasing of questions, moderate interaction, and guide discussion. Although instructed not to make judgments during the initial workshop explanation, T1 wrote that it was hard to probe without judging and analyzing the role-players, and the trainees did make judgmental statements. The facilitators should have intervened to remind the trainees that the goals of the training were to understand their own and other people's behaviour and values as highlighted in role-play and that making judgments of role-players' statements and actions does not lead to those goals.

Another tendency among trainees was to focus on problem-solving, based on the assumption that their cultural perspective and values were "correct" or "normal." For example, T3 said, "You said that something happened before. There were complaints.

What were the complaints?" This would have been a good opportunity for the facilitator to step in and redirect the questions and comments towards the feelings and motivations of the role-players.

\section{Analysis of Trainee Values}

The transcription extracts were classified into the aforementioned eight themes. Evidence of how values were highlighted in the role-play and how trainees related to them are shown in Appendix A and are also discussed below, together with additional themes that were identified. 


\section{Temporality and Progressiveness}

These themes were not commented on by the trainees. This is somewhat surprising in that the role-players attempted to contrast these themes by showing opposing attitudes towards the time required and the process in the development of the English Zone.

However, it was possible that these themes were obvious so trainees did not feel the need to discuss them.

\section{Hierarchy}

T3's questions "What's his position?" and "how long [has] your colleague has been at this university?" to A1 about people's status at this new job suggest that seniority was an important factor in how people should behave.

\section{Relationship and Face}

The trainees knew that relationships were an asset in the workplace: "I don't really want to step on anyone's toes" (T3). Moreover, saving face was T2's concern: "What's that going to look like to the head of the department?"

\section{Risk}

The trainees generally showed caution and self-control based on their experience, for example: "A lot of it is learning where to jump in but also when to hold back" (T3).

\section{Process}

Trainees 1 and 2 showed that if they were in similar situations they would like to involve other people, "like who we need to involve" (T2) and "We haven't talked to anybody you know we need to talk to, we need to inform others" (T1), showing that they believed that there was a certain process that should have been followed.

\section{Group Orientation}

They also showed awareness of group orientation in different cultural contexts. T1 said, "So I think it depends on the culture, you can work individually, but in most Japanese contexts ... you have to involve others." T2 countered, "There're just four of us, we're all foreigners. We do our own stuff individually and occasionally cooperate," showing that it was easier in her work context for her foreign coworkers to work independently, demonstrating a differing value placed on group orientation.

\section{Motivation}

The complexity of motivation was illustrated by two trainees who identified with both role-players. $\mathrm{T} 2$ described $\mathrm{A} 2$ in the following way:

He's stuck in his ways, really complacent, maybe a bit jaded ... and I think also . people who've been around for a while are a little bit intimidated by new people who are enthusiastic. They're afraid that, for example, um, they might look bad in comparison...

She interpreted A2's apparent lack of enthusiasm to work on this new project as either a wish to avoid extra work: "[He] doesn't want to take on anything extra because he doesn't really see any benefit" or a feeling of insecurity when confronted with the energy and enthusiasm of his new colleague: "Someone asks me to do it because I don't really like want to step on anybody's toes” (T2). T3, however, shared how, as a new member of her department, she had volunteered to help with a project but was warned by a colleague to leave the work to others with more expertise. In her view, an apparent lack of motivation to work on a project could come from a desire to avoid creating problems for others. She went on to point out the need to look beyond the surface of a situation and to be aware of various peoples' underlying motivations: "I don't want to be offensive but I don't think it's quite fair to write people off at the top as jaded or a terrible mentor .. because I think that it's more complicated" (T3).

\section{Mentoring}

One of two themes that were not anticipated was mentoring. T2 said to A2,

Well, if I were you, I would email her and say you've got some great ideas, why don't you email them to me? Then I will show you how ... what we need to do to make these happen, like who we need to involve .... . but again that's up to you to teach her ... if you're going to be a real mentor ...

She believed that mentoring is about showing, teaching, and leading by example. 


\section{Consensus Building:}

Another unanticipated theme was consensus building. T1 shared her experience of working in Japan: "So I think depending on the culture, you, you can work individually, but in most Japanese contexts, you can not go ahead and do something individually on your own, you have to involve others." This shows how, in her opinion, consensus building is context dependent, and in a Japanese environment it is the norm.

The trainees' values were not binary, simply one or the other, but fell along a contextspecific spectrum. They showed awareness of both reference and contrast values, although empathizing and sharing experiences more with Japanese culture. In one of the surveys, in response to the question "What ideas or values did you relate to the most?" T2 wrote, "Power dynamics, politics in the workplace, dealing with senior coworkers as both a younger person and a woman in this male-dominated culture." This revealed that the trainee's focus was clearly on her workplace culture. Trainees naturally tend to focus on the role-play context to seek to improve the outcome, such as the mentoring advice given by $\mathrm{T} 2$, whereas the challenge for the trainers is to direct them to reflect on improving their awareness of their own values. However, by making "a slip" in the role-play that led the trainees to focus on the Japanese setting, the trainers' ability to do that was restricted.

\section{Limitations and Opportunities}

Trainees must be given clear instructions throughout a CCM session in regards to being nonjudgmental of role-players' cultures in order to maintain a level of objectivity. The work of the interviewers and lead facilitator was not as effective as it needed to be because it was unclear whose role this would be among the trainers. Furthermore, this was the first opportunity for the interviewers, and they did not possess the experience needed to guide the trainees. This was a weakness that should have been discussed at the planning stage and underlines the importance of preparing all interviewers and the lead facilitator adequately.

The method of planning the workshop was built on the trainers identifying themes and consciously including them in the scenario. This guided both the trainees and trainers towards associating with these values. Another method would have been to choose a more loosely defined or spontaneous role-play, to achieve more diverse trainee interpretations and values. This is an approach that could be explored in future CCM workshops.

When a workshop is only about one hour, rather than an ongoing training programme, it can nevertheless provide trainees with an experience of how CCM is conducted and also an opportunity to reflect on their own and other trainees' values. However, more guidance and time should be given to the trainees for the post-CCM workshop evaluation survey. An explanation of its purpose could be included on the printed survey handout and the facilitator could also provide a verbal explanation and invite questions before the trainees start to fill it out. It should be emphasised that the aim of the survey is to increase the trainees' understanding of their own and other cultural values by reflecting deeply on the personal feelings, memories, and ideas that were stimulated during the CCM session.

\section{Conclusion}

The culture contrast method is evolving in its application and implementation as a versatile intercultural training method. In Japan, it has been used successfully to help international students with cultural adjustment and to raise awareness among Japanese students of different cultural expectations that they may encounter overseas. Moreover, CCM is a valuable tool when used for faculty development and for these reasons, we demonstrated CCM at the JALT2018 conference.

For CCM to progress, it is essential that trainers examine the effectiveness of their workshops; an ideal approach is to undertake longitudinal studies whenever possible. However, in a short workshop like the one outlined in this paper, a different approach is required. Due to the absence of an established methodology, it was decided to consider (a) the process through which CCM is designed and implemented and (b) the methods in which the trainees' reactions are collected and analysed.

This research has highlighted that presenting a culturally nonspecific context is crucial, as is giving clear instructions and guidance to the trainees to create the environment needed for objective understanding. Although we determined that most of the cultural contrasts that had been simulated were noted by the trainees, additional themes that were not anticipated were also revealed in their discussions. The degree to which the trainees identified and related to the values represented in the role-play were examined. However, without a scale of measurement it was not possible to measure and compare the extent of their awareness. This needs to be addressed in future research.

We are still at the exploratory stage of how to evaluate the efficacy of short CCM workshops and will continue to review and refine our methods of evaluation. Nevertheless, this data and its analysis can provide a rich source of feedback to CCM trainers and researchers for the implementation and evaluation of future CCM training workshops. 


\section{Acknowledgments}

We would like to thank Elisabeth Fernandes, Donna Fujimoto, Sachiko Nakamura, and anonymous reviewers for their support and feedback in the implementation, transcription, and commenting on this project and paper.

\section{Bio Data}

Alan Simpson is a lecturer at Miyazaki International College, and coordinator of the JALT Business Communication SIG. He has an MSc in TESOL from Aston University, and has research interests in English for specific purposes, business communication, and intercultural training.

Amanda Gillis-Furutaka is a professor in the Faculty of Foreign Studies, Kyoto Sangyo University, and Program Chair of the JALT BRAIN SIG. She has an MA in TESOL from the University of Birmingham and a PhD in music from Goldsmiths College, University of London. Having lived and taught in Europe, South America, and Asia, and raised three bicultural children, she has a wide range of research interests, the most recent of which is intercultural training.

Alexis Pusina is a lecturer at Tokyo International University. He possesses an MA in International and Multicultural Education from the University of San Francisco. His research interests include academic writing best practices, ethnic studies, and intercultural conflict resolution.

Daniel Lilley is an assistant professor at Osaka Gakuin University, where he is in charge of inbound student exchange. His areas of interest are social justice and intercultural studies. His current research focus is CCM training for short-term students to Japan.

Margaret Kim is an associate professor at Otemae University. She earned her MA in TESOL from the School for International Training. She has had the experience of teaching in Cambodia, Malaysia, South Africa, the United States, and Japan. Her current research interests are gender issues, intercultural training, and public speaking.

\section{References}

Branch, R. (2009). Instructional design: The ADDIE approach. Boston, MA: Springer. https://doi.org/10.1007/978-0-387-09506-6

Fujimoto, D. (2004). Adapting the contrast culture method to the classroom. Journal of Intercultural Communication, 7, 43-61.
Hiratsuka, H. (2015). A training guide for contrast culture method (version 1): Managing preparation, implementation, and evaluation. Aoyama Information Science, 43(1), 12-17.

Hiratsuka, H., \& Fujimoto, D. (2012) A training evaluation of the contrast culture method for international graduate students in Japan. Journal of Intercultural Communication, 15, 93-108.

Hiratsuka, H., Suzuki, H., \& Pusina, A. (2016). Explaining the effectiveness of the contrast culture method for managing interpersonal interactions across cultures. Journal of International Students, 6(1), 73-92.

Kimmel, P. R. (1995). Facilitating the contrast-culture method. In S. M. Fowler \& M. G. Mumford (Eds.), Intercultural sourcebook: Cross-cultural training methods, 1, 69-79. Boston, MA: Intercultural Press.

Stewart, E., Danielian, J., \& Foster, R. (1969). Simulating intercultural communication through role-playing (Technical Report 69-7). Alexandria, VA: George Washington University Human Resources Research Office.

Stewart, E. C. (1995). Contrast-culture training. In S. M. Fowler \& M. G. Mumford (Eds.), Intercultural sourcebook: Cross-cultural training methods, 1, 47-56. Boston, MA: Intercultural Press.

Wasilewski, J. H., \& Kawakami, H. S. (2012). Edward C. Stewart: Cultural dynamics pioneer. International Journal of Intercultural Relations, 36(6), 869-884. https://doi.org/10.1016/j.ijintrel.2012.08.012

Appendix A

Key Themes \& Values Highlighted in This CCM Workshop

\begin{tabular}{|l|l|l|}
\hline Theme & $\begin{array}{l}\text { Evidence of how theme is highlighted by actors in } \\
\text { role-play/ interviews }\end{array}$ & $\begin{array}{l}\text { Evidence of theme } \\
\text { identified by trainees' } \\
\text { comments }\end{array}$ \\
\hline Temporality & $\begin{array}{l}\text { "Let's see," and other stalling tactics (A2) } \\
\text { "Christmas is around the corner. We should start } \\
\text { planning." "We should start planning now." (A1) } \\
\text { "No, no, no, no. You're jumping into it too soon." } \\
\text { "I was thinking at some stage next year. I wasn't } \\
\text { thinking this Christmas." (A2) } \\
\text { "Next year is too late, don't you think?" (A1) } \\
\text { "I'm not sure we're on the same time frame." (A1) } \\
\text { "That process will probably take 6 months to a year, } \\
\text { at least." (A2) }\end{array}$ & None identified \\
\hline
\end{tabular}




\begin{tabular}{|c|c|c|}
\hline Hierarchy & $\begin{array}{l}\text { "Let's go straight to the top and ask the person in } \\
\text { charge." (A1) } \\
\text { "He's a full-time tenured professor." "I've just been } \\
\text { hired as a professor. I'm new." "We've been assigned } \\
\text { together and I don't want to step over him. It should } \\
\text { be something that has been talked about together. I } \\
\text { can't step above him.” (A1) }\end{array}$ & $\begin{array}{l}\text { "How long your } \\
\text { colleague has been } \\
\text { at this university?" } \\
\text { "What's his position?" } \\
\text { (T3) }\end{array}$ \\
\hline $\begin{array}{l}\text { Relationship \& } \\
\text { face }\end{array}$ & $\begin{array}{l}\text { "I don't want to step over him or anything." (A1) } \\
\text { "I understand his point. He has been at the school } \\
\text { longer than I have." (A1) }\end{array}$ & $\begin{array}{l}\text { "What's that going to } \\
\text { look like to the head of } \\
\text { the department?" (T2) } \\
\text { "I don't really want to } \\
\text { step on anyone's toes." } \\
\text { (T3) }\end{array}$ \\
\hline Risk & $\begin{array}{l}\text { "This will definitely be a challenge." "We have to plan } \\
\text { this properly." (A2) } \\
\text { "It will be so exciting. I can't wait!" "But we have to } \\
\text { try. If we don't try, how do we know? Let's just go for } \\
\text { it, let's take this risk?" (A1) } \\
\text { "I think he's not really into taking any risks." (A1) }\end{array}$ & $\begin{array}{l}\text { "A lot of it is learning } \\
\text { where to jump in but } \\
\text { also when to hold } \\
\text { back." (T3) }\end{array}$ \\
\hline Process & $\begin{array}{l}\text { "When are we going to have our first planning } \\
\text { meeting? I need to know because l'm going to invite } \\
\text { all the different ... a member from each faculty, so } \\
\text { we're going to have to ask the admin staff to join us, } \\
\text { so that everybody knows." (A2) } \\
\text { "Why does everyone have to be involved? Why don't we } \\
\text { just go right to the top and tell them our idea?" (A1) } \\
\text { "We should just go straight to whoever we have to go } \\
\text { to. We don't have to go to all these committees and } \\
\text { everything." (A1) } \\
\text { "I've been here many years now ... erm ... It's a process } \\
\text { that works... And a lot of people need to be involved, } \\
\text { and going through all the necessary steps, making sure } \\
\text { that everyone around us knows what's happening, and } \\
\text { we need their active help and support and for them to } \\
\text { be actively involved in every step is very important. And } \\
\text { regardless of how long it takes." (A2) } \\
\text { "We've got to be very careful not to tread on people's } \\
\text { toes." (A2) }\end{array}$ & $\begin{array}{l}\text { "Like who we need to } \\
\text { involve" (T2) } \\
\text { "For example people } \\
\text { who are involved, } \\
\text { or even at the } \\
\text { administrative level, } \\
\text { or other departments } \\
\text { whose students will be } \\
\text { participating will have } \\
\text { to be involved." (T1) } \\
\text { "We haven't talked to } \\
\text { anybody you know } \\
\text { we need to talk to, we } \\
\text { need to inform other." } \\
\text { (T1) }\end{array}$ \\
\hline
\end{tabular}

\begin{tabular}{|c|c|c|}
\hline $\begin{array}{l}\text { Group } \\
\text { orientation }\end{array}$ & $\begin{array}{l}\text { "I talked to some staff on the way here." (A1) } \\
\text { "That's bit soon, isn't it? We haven't even decided } \\
\text { when we're going to have our first planning } \\
\text { meeting." (A2) } \\
\text { "We should get the idea out there." (A1) } \\
\text { "Who's this we? We haven't even had our first } \\
\text { meeting to plan this." (A2) } \\
\text { "He wants to make sure that everyone agrees with } \\
\text { it." (A1) } \\
\text { "I was thinking it had to be done the correct way } \\
\text { and it would take a lot more talking and planning } \\
\text { rather than just throwing ideas out and saying let's } \\
\text { do it right now." "First of all, we would have to get } \\
\text { cooperation from other departments, from other } \\
\text { teachers, get opinions, put that together and have } \\
\text { some kind of plan in place." "There are a lot of things } \\
\text { that happen behind the scenes that I don't think she } \\
\text { realizes." (A2) }\end{array}$ & $\begin{array}{l}\text { "So I think it depends } \\
\text { on the culture, you } \\
\text { can work individually, } \\
\text { but in most Japanese } \\
\text { contexts ... you have } \\
\text { to involve others." (T1) } \\
\text { "We do our own } \\
\text { stuff individually, } \\
\text { and occasionally } \\
\text { cooperate." (T2) } \\
\text { "In the Japanese } \\
\text { context, others will } \\
\text { have to be involved } \\
\text {... depending on } \\
\text { the culture you can } \\
\text { work individually, } \\
\text { but in most Japanese } \\
\text { contexts you } \\
\text { cannot go ahead } \\
\text { and do something } \\
\text { individually. You have } \\
\text { to involve others. . } \\
\text {. So knowing the } \\
\text { Japanese context, I } \\
\text { think your colleague } \\
\text { has a rationale." (T1) }\end{array}$ \\
\hline Motivation & $\begin{array}{l}\text { (Lack of motivation:) "If you want to do this yourself, } \\
\text { you're very welcome to do so." (A2) } \\
\text { "I feel ... I'm stoked, I'm like excited by this idea, I } \\
\text { really am. I cannot wait." "I'm new here and I want to } \\
\text { make a difference." (A1) } \\
\text { [About A1] "I appreciate enthusiasm but she could to } \\
\text { tone it down a little bit. And channel her enthusiasm } \\
\text { into helping the students. .. When it comes to } \\
\text { planning something as big as an English Zone room, } \\
\text { a new project at the university, l'm not quite sure } \\
\text { whether her enthusiasm would be welcomed." (A2) }\end{array}$ & $\begin{array}{l}\text { "[He] doesn't want to } \\
\text { take on anything extra } \\
\text { because he doesn't } \\
\text { really see any benefit." } \\
\text { (T2) } \\
\text { "People who have been } \\
\text { around for a while are } \\
\text { a little bit intimidated } \\
\text { by new people who are } \\
\text { enthusiastic." (T2) }\end{array}$ \\
\hline
\end{tabular}




\begin{tabular}{|l|l|l|}
\hline Progressiveness & $\begin{array}{l}\text { "I don't care about the past, let's move forward." (A1) } \\
\text { "But change, right? I think it's a good time to } \\
\text { change and I'm ready for that. But he was hesitant } \\
\text { about that." "I want to move ahead. I want to move } \\
\text { forward. Who cares about the past? Let's move } \\
\text { forward." (A1) }\end{array}$ & Noned \\
\hline
\end{tabular}

Note. (A1), (A2) role-play actors, (T1)-(T4) trainees.

\section{Appendix B}

Written Feedback From Trainees

\section{Question 1. Do you feel this session was useful for you? Why? Why not?}

Trainee 1: Yes, because it really reminded me of my colleagues and my situation and it helped me to probe their thinking/personal situation (and mine).

Trainee 2: Interesting and insightful. Other participants had ideas I had not considered and it made me re-think.

Trainee 3: I thought it was ok, as I have attended a number of these sessions and are getting used to them. I find that the IC contrast is quite useful in drawing attention to a number of the differences between the two actors, some of which may be hidden/ unconscious to the eyes or attention of the audience. The more of these I attend, the more I can reflect on different aspects of pragmatics, which can then relate to transferability to what $\mathrm{I}$ am doing in class.

\section{Question 2. What values or ideas did you relate to the most, and why?}

Trainee 1: Actually, both sides, but the idea of coming in new and not knowing how things "really work."

Trainee 2: Power dynamics, politics in the workplace, dealing with senior co-workers as both a younger person and a woman in this male dominated culture.

Trainee 3: For me, the value and ideas in these sessions is in that they endeavor to reflect some aspect of a true experience, and that's often what the audience is able to 'hang' their connection and experience on. As a role-player myself, I think using an element of reality adds credibility and realism to what the audience sees and observes.

\section{Question 3. Please write a paragraph about your experience and thoughts in this session:}

Trainee 1: This was really interesting for me. It was hard to probe without judging or analyzing. It must have been difficult to stay in character!

Trainee 2: No response

Trainee 3: My only issue with these sessions to date, and one that I first realized from the first time I observed one, was that I feel that they tend to go on for a while too long after I suspect that the audience had 'got it'. Switching gears somehow mid-role-play to add a 2nd aspect to the discussion may help with that. 